\title{
Primary extra-nodal diffuse large B-cell lymphoma: A prognostic analysis of 141 patients
}

\author{
HAORUI SHEN, ZHANG WEI, DAOBIN ZHOU, YAN ZHANG, XIAO HAN, \\ WEI WANG, LU ZHANG, CHEN YANG and JUN FENG
}

Department of Hematology, Peking Union Medical College Hospital, Beijing 100730, P.R. China

Received July 18, 2017; Accepted December 11, 2017

DOI: $10.3892 / 01.2018 .8803$

\begin{abstract}
Diffuse large B-cell lymphoma (DLBCL) is the most common subtype of lymphoma. Approximately $40 \%$ of DBLCL originates from extra-nodal sites, but the diversity of clinical presentations and the genetic and molecular alterations indicate that extra-nodal DLBCLs may be distinct disease entities. The aim of the present study was to highlight the various aspects of primary extra-nodal DLBCL (PE-DLBCL) based on a single center cohort. The data from 141 patients with PE-DLBCL treated at Peking Union Medical College Hospital were retrospectively evaluated. The primary extra-nodal sites involved were the gastrointestinal tract $(n=42)$, central nervous system (CNS; $n=38)$, breast $(n=19)$, adrenal gland $(n=15)$, female genital system (FGS; $n=12)$, thyroid $(n=8)$ and bone $(n=7)$. The median overall survival rate was 28 months (range, 1-116). Multivariate analysis demonstrated that an International Prognostic Index (IPI) $\leq 2(\mathrm{P}=0.049)$, complete remission $(\mathrm{CR})$ achieved following first-line therapy $(\mathrm{P}=0.001)$ and chemotherapy combined with rituximab $(\mathrm{P}<0.001)$ were positive prognostic factors. Patients with DLBCL with primary adrenal gland or female genital system (FGS) involvement exhibited a significantly higher risk of $\mathrm{CNS}$ recurrence $(\mathrm{P}<0.05)$. Rituximab treatment may have reduced the likelihood of CNS recurrence $(\mathrm{P}=0.005)$, whereas prophylaxis with intrathecal injection alone was not sufficient for prevention ( $\mathrm{P}>0.05)$. In conclusion, IPI $>2$ and the lack of a CR following first-line therapy were independent prognostic risk factors for PE-DLBCL. Patients with primary adrenal gland or FGS involvement exhibited a higher risk of CNS relapse. Rituximab had a positive impact on the survival of patients with PE-DLBCL, also reducing the likelihood of CNS relapse.
\end{abstract}

Correspondence to: Dr Jun Feng, Department of Hematology, Peking Union Medical College Hospital, 1 Shuaifuyuan Wangfujing Street, Beijing 100730, P.R. China

E-mail: fengjun@pumch.cn

Key words: extra-nodal lymphoma, central nervous system, rituximab, prognostic factors

\section{Introduction}

Lymphoma may arise from a nodal or extra-nodal origin, and the number of patients with extra-nodal non-Hodgkin's lymphoma (NHL) is rapidly increasing $(1,2)$. The exact designation of primary extra-nodal NHL (PE-NHL) is controversial, particularly when both nodal and extra-nodal sites are involved; a number of studies have described PE-NHL as presenting only in extra-nodal sites, with no visible lymphadenopathy on imaging $(3,4)$, while others have used a broader definition, in which extra-nodal disease with regional or distant involved lymph nodes is included $(1,5)$. In the present study, the former definition was selected. The incidence of PE-NHL varies between countries, accounting for 15-48\% of NHL cases. The most common pathological type of PE-NHL is diffuse large B-cell lymphoma (DLBCL), representing 71-81.3\% of cases $(6,7)$. Although lymphomas may involve almost all extra-nodal organs, different organs are involved at different frequencies. Primary extra-nodal DLBCLs (PE-DLBCLs) are common in the gastrointestinal (GI) tract, and are relatively uncommon in the central nervous system (CNS), thyroid, breast, female genital system (FGS), testis, skin, adrenal gland, pancreas, bone or other sites $(6,8,9)$.

CNS relapse is nearly always fatal, and the overall risk of CNS relapse of patients with DLBCL is 5\% (10). However, the incidence is much higher in patients when breast, adrenal gland or testicular sites are involved.

The diversity of clinical presentations suggests that PE-DLBCLs are distinct entities, and efforts regarding the risk factors and prevention methods for CNS recurrence are inconclusive. Thus, the present study retrospectively analyzed the clinical features, response to therapy, long-term outcomes and CNS relapse of patients with PE-DLBCL at the Department of Hematology (Peking Union Medical College Hospital, Beijing, China).

\section{Patients and methods}

Patients. A total of 677 patients (median age 58 years, age range 12-78 years; male to female ratio 71:10) diagnosed with DLBCL and treated at Peking Union Medical College Hospital between December 2003 and December 2013, and 141 patients diagnosed with PE-NHL were evaluated. The median age was 58 (range, 12-78), and the sex ratio of male and 
female was 71:70. All biopsies were classified according to the World Health Organization classification system (11) and were analyzed by immunohistochemistry. When lymphomas were contiguous with neighboring organs, the site with the largest area of involvement was defined as the dominant site. The Ann Arbor stage for PE-NHL involving bilateral paired organs or diffuse lesions of an organ remains a source of contention, but in the present study, these situations were considered as stage IV. Patients presenting with either systemic disease, primary nodal NHL with secondary extra-nodal involvement, infection with human immunodeficiency virus, hepatitis $\mathrm{C}$ or $\mathrm{B}$, or recurrent lymphoma following previous treatment were excluded from the study.

Measurements of complete blood count and biochemical parameters, including serum lactate dehydrogenase (LDH), serum total protein, serum albumin, creatinine, serum urea, uric acid, liver enzymes and bilirubin, and bone marrow aspiration and trephine biopsy, whole body computed tomography scan, fluorodeoxyglucose positron emission tomography (FDG-PET) and magnetic resonance imaging (MRI) of the brain were performed prior to and following treatment. Patients were staged and evaluated according to the Ann Arbor classification (12) and the International Prognostic Index (IPI) score (13). Patients with primary gastrointestinal DLBCL were evaluated by Lugano classification (14).

All procedures were performed in accordance with the ethical standards of the responsible Ethics Committee of Peking Union Medical College Hospital (Beijing, China) on human experimentation (institutional and national) and with the Declaration of Helsinki (1975), as revised in 2000. Written informed consent was obtained from all patients included in the study.

Treatment and response. First-line therapy for patients with primary CNS-DLBCL (PCNS-DLBCL) was high-dose methotrexate (HD-MTX)-based combined chemotherapy $\left(\mathrm{CT} ; 3 \mathrm{~g} / \mathrm{m}^{2}\right.$ over $4 \mathrm{~h}$ rapid infusion time; the cycle length of HD-MTX transfusion was 28 days and the number of cycles was 6-8.) and 14 patients received radiotherapy (RT; 40-50 Gy) after CT. The first-line treatment for the remaining PE-DLBCL patients was CHOP (cyclophosphamide $750 \mathrm{mg} / \mathrm{m}^{2}$ iv $\mathrm{d} 1$, doxorubicin $50 \mathrm{mg} / \mathrm{m}^{2}$ iv d1, vindesine $1.4 \mathrm{mg} / \mathrm{m}^{2}$ iv d1, prednisone $100 \mathrm{mg}$, po d1-5) or CHOP-like regimen combined with rituximab (R-CHOP. rituximab $375 \mathrm{mg} / \mathrm{m}^{2} \mathrm{~d} 1$ ). The regimen was given every 21 days for 6-8 cycles. However, 49 patients selected treatment without rituximab due to its high cost. A total of 32 patients underwent surgery for definitive diagnosis and 10 patients for the management of complications.

The National Comprehensive Cancer Network (NCCN) (15) guidelines divide patients into low (score, $0-1$ ), moderate (score, 2-3) and high-risk (score, 4-6) CNS relapse groups based on the IPI (5 scores) and kidney or adrenal involvement (1 score). Due to the retrospective nature of the present study, scoring procedures were not standardized and not all variables were available for each patient. In 2012, our center began administering intravenous injections of HD-MTX for the prevention of CNS recurrence. A total of 68 patients with a moderate or high risk of CNS relapse received prophylaxis, including 36 patients that only received intrathecal injection, 19 patients that only received the intravenous injection of HD-MTX $\left(1 \mathrm{~g} / \mathrm{m}^{2}\right.$ for 4 cycles) and 13 patients that received both.
The response to treatment was assessed, following the completion of initial therapy, according to the International Working Group criteria (16) as complete remission (CR), partial remission (PR), stable disease (SD) or progressive disease (PD).

Follow-up. Patients were followed up every 3 months for the first 3 years after treatment and every 6 months thereafter. Routine examinations were performed during the follow-up period, including physical examination, laboratory tests, echocardiography, and a whole-body computed tomography scan or FDG-PET. Lumbar puncture head MRIs were performed on those with primary CNS involvement or the clinical symptoms of CNS relapse. The final follow-up date was November 31, 2016. Among all 141 patients, 16 were lost to follow-up.

Statistical analysis. Overall survival (OS) was calculated from the date of diagnosis to the date of last follow-up or mortality from any cause. Progression-free survival (PFS) was evaluated from the date of diagnosis to the date of disease progression or relapse. Statistical analysis was performed using SPSS 19.0 software (IBM Corp., Armonk, NY, USA). The Kaplan-Meier method and the log-rank test were used for univariate analysis and the generation of survival curves. All factors with P-values $<0.10$ were included in the multivariate analysis using the Cox proportional hazards model. Differences were evaluated using a two-tailed test; $\mathrm{P}<0.05$ was considered to indicate a statistically significant difference.

\section{Results}

Clinical characteristics. Patients with PE-DLBCL accounted for $20.8 \%$ of all the patients with NHL during the study period. The characteristics of the patients at diagnosis are summarized in Table I. The presence of B symptoms was less common in patients with primary CNS, breast, thyroid gland or FGS involvement than it was for other sites. The majority of patients were classified as clinical stage I-II $(87 ; 61.7 \%)$, whereas the number of patients at stage III/IV was highest for patients with primary adrenal gland $(12 / 15 ; 80.0 \%)$ and bone $(6 / 7 ; 85.7 \%)$ involvement. The overall distribution of patients with PE-DLBCL is presented in Table II.

Response to treatment and survival. The median OS and PFS times of patients with PE-DLBCL were 28 months (range, 1-116 months) and 17 months (range, 1-108 months), respectively. The OS and PFS rates differed between patients with the primary involvement of different sites (Table III). Although the prognosis was improved for patients with primary thyroid DLBCL (PT-DLBCL), compared with those primary adrenal gland DLBCL (PA-DLBCL), the difference was not statistically significant $(\mathrm{P}=0.178$; Fig. 1$)$. The median $\mathrm{OS}$ times of patients with primary GI tract, CNS, adrenal gland, breast, FGS, thyroid and bone involvement were 36.5 months (range, 1-108), 29 months (range, 1-112), 14 months (range, 2-94), 25 months (range, 3-79), 20 months (range, 3-60), 22 months (range, 16-50) and 18.5 months (range, 15-37), respectively, and the PFS times were 25.5 months (range, 1-108), 24 months (range, 1-85), 10 months (range, 1-50), 20 months (range, 
Table I. Patient characteristics according to the primary involved site.

\begin{tabular}{|c|c|c|c|c|c|c|c|}
\hline Characteristics & GI tract & $\mathrm{CNS}$ & Breast & Adrenal gland & FGS & Thyroid gland & Bone \\
\hline Total & 42 & 38 & 19 & 15 & 12 & 8 & 7 \\
\hline \multicolumn{8}{|l|}{ Age, years } \\
\hline Median & 56 & 58 & 53 & 62 & 59 & 61 & 56 \\
\hline Range & $15-77$ & $17-78$ & $20-77$ & $43-73$ & $20-77$ & $54-77$ & $12-68$ \\
\hline Age $>60$ years & 17 & 14 & 3 & 9 & 5 & 4 & 2 \\
\hline \multicolumn{8}{|l|}{ Sex } \\
\hline Male & 28 & 27 & 0 & 8 & 0 & 2 & 6 \\
\hline Female & 14 & 11 & 19 & 7 & 12 & 6 & 1 \\
\hline B symptoms & 24 & 4 & 2 & 7 & 3 & 0 & 5 \\
\hline Increased serum lactate dehydrogenase & 18 & 13 & 3 & 10 & 4 & 4 & 3 \\
\hline ECOG performance status $>1$ & 13 & 22 & 1 & 7 & 0 & 4 & 3 \\
\hline \multicolumn{8}{|l|}{ Ann Arbor stage } \\
\hline $\mathrm{I}+\mathrm{II}$ & 25 & 34 & 10 & 3 & 6 & 8 & 1 \\
\hline $\mathrm{III}+\mathrm{IV}$ & 17 & 4 & 9 & 12 & 6 & 0 & 6 \\
\hline \multicolumn{8}{|l|}{ Lugano stage } \\
\hline I-IIE & 33 & - & - & - & - & - & - \\
\hline IV & 9 & - & - & - & - & - & - \\
\hline \multicolumn{8}{|l|}{ International prognostic index } \\
\hline Low & 12 & 8 & 11 & 0 & 6 & 3 & 2 \\
\hline Low-intermediate & 8 & 14 & 4 & 4 & 1 & 1 & 2 \\
\hline High-intermediate & 11 & 5 & 4 & 2 & 5 & 1 & 2 \\
\hline High & 11 & 11 & 0 & 9 & 0 & 3 & 1 \\
\hline Bone marrow involvement & 2 & 0 & 2 & 1 & 1 & 0 & 1 \\
\hline \multicolumn{8}{|l|}{ Hans classification } \\
\hline $\mathrm{GCB}$ & 9 & 3 & 5 & 0 & 2 & 3 & 1 \\
\hline Non-GCB & 11 & 14 & 6 & 5 & 3 & 2 & 3 \\
\hline \multicolumn{8}{|l|}{ Treatment } \\
\hline Chemotherapy without rituximab & 7 & 22 & 7 & 4 & 6 & 0 & 3 \\
\hline Chemotherapy with rituximab & 35 & 17 & 12 & 9 & 6 & 8 & 4 \\
\hline Chemotherapy with surgery & 23 & 5 & 5 & 0 & 8 & 4 & 0 \\
\hline \multicolumn{8}{|l|}{ Risk of CNS relapse ${ }^{a}$} \\
\hline Low & 12 & - & 11 & 0 & 7 & 3 & 2 \\
\hline Moderate & 18 & - & 8 & 4 & 0 & 2 & 3 \\
\hline High & 12 & - & 0 & 11 & 5 & 3 & 2 \\
\hline \multicolumn{8}{|l|}{ CNS prophylaxis } \\
\hline Intrathecal injection & 19 & - & 1 & 5 & 3 & 4 & 4 \\
\hline Intravenous injection of methotrexate & 8 & - & 5 & 5 & 0 & 0 & 1 \\
\hline Combined prophylaxis & 3 & - & 5 & 2 & 2 & 1 & 0 \\
\hline Median follow-up time, months & $36(1-108)$ & $29(1-116)$ & $22(3-60)$ & $14(1-94)$ & $13(6-84)$ & $24(16-51)$ & $16(9-20)$ \\
\hline Loss to follow-up & 0 & 7 & 5 & 0 & 1 & 0 & 3 \\
\hline
\end{tabular}

${ }^{a}$ Risk of CNS relapse was based on the National Comprehensive Cancer Network guidelines. GI, gastrointestinal; CNS, central nervous system; FGS, female genital system; ECOG, Eastern Cooperative Oncology Group; GCB, germinal center B-cell.

3-79), 11 months (range, 3-84), 22 months (range, 1-50) and 12.5 months (range, 9-20), respectively.

A total of 59 patients with PE-DLBCL achieved CR (47.5\%) and 15 achieved PR (12.1\%), resulting in a total response rate (RR) of $59.6 \%$. The RR for patients with PT-DLBCL was
$100 \%$, while that of those with primary bone, breast, FGS, CNS, GI tract, and adrenal gland involvement was 75, 64.3, 63.6, 58.1, 57.1 and 33.3\%, respectively. Patients treated with rituximab exhibited a better RR than those not treated with rituximab (68.2 vs. 34.1\%). 
Table II. Distribution of primary extra-nodal diffuse large B-cell lymphoma cases.

\begin{tabular}{lc}
\hline Extra-nodal sites & No. of patients \\
\hline Gastrointestinal tract & 42 \\
Stomach & 20 \\
Colon & 8 \\
Ileocecum & 7 \\
Small intestine & 7 \\
Central nervous system & 38 \\
Deep brain tissue & 34 \\
Multiple lesions & 20 \\
Breast & 19 \\
Unilaterally involved & 19 \\
Adrenal gland & 15 \\
Bilaterally involved & 8 \\
Female genital system & 12 \\
Ovary & 6 \\
Cervix & 3 \\
Uterine body & 3 \\
Both cervix and vagina & 2 \\
Thyroid gland & 8 \\
Bone & 7 \\
Axial skeleton & 5 \\
Skull & 2 \\
Pelvis and spinal column & 2 \\
Pelvis & 1 \\
Limbs & 2 \\
\hline &
\end{tabular}

Prognostic factors. The survival rate was not significantly influenced by age, sex, Eastern Cooperative Oncology Group performance status (17), primary site or bone marrow involvement. Univariate analysis demonstrated that elevated serum LDH, B symptoms, Ann Arbor stage, inclusion of rituximab, CR following first-line therapy and IPI significantly affected survival (Fig. 2). In the multivariate analysis, IPI $\leq 2, \mathrm{CR}$ following first-line treatment and combination with rituximab were independent predictive factors for OS in patients with PE-DLBCL; the latter two were also significantly associated with PFS (Table III). Patients could be divided into four groups with different prognoses on the basis of IPI (Fig. 3).

Of the patients with primary GI DLBCL (PGI-DLBCL), 23 received surgery combined with $\mathrm{CT}, 20$ of which were Lugano stage I-IIE and 8 (40.0\%) of which succumbed to the primary disease during follow-up. A total of 8 patients with primary FGS-DLBCL (PFGS-DLBCL) and 5 patients with primary breast DLBCL (PB-DLBCL) underwent surgery. However, no statistically significant differences were observed in the 3-year OS and PFS rates between patients who had and had not undergone surgery (Table IV).

A total of 22 patients with PCNS-DLBCL received CT alone, and 9 were treated with CT followed by RT. The 3 -year OS rates of the two groups were 57.8 and $66.7 \%$ respectively, and the 3-year PFS rates were 56.8 and $62.5 \%$ respectively, but no significant differences were observed between the two groups $(\mathrm{P}=0.592$ vs. $\mathrm{P}=0.703)$.

Analysis of CNS relapse. A higher rate of CNS relapse was observed in patients with primary FGS $(6 / 11,54.5 \%)$ and adrenal gland $(3 / 15,20.0 \%)$ involvement compared with other sites, and the difference was statistically significant (Table V). A significant trend towards a prolonged time to CNS relapse following intravenous rituximab treatment was observed ( $\mathrm{P}=0.003$; Fig. 4), but neither intravenous HD-MTX nor intrathecal injection reduced the incidence of CNS recurrence $(\mathrm{P}=0.689$ and $\mathrm{P}=0.876$, respectively).

\section{Discussion}

PE-DLBCL is a heterogeneous disease with various clinical manifestations and molecular alterations at different anatomical sites. The majority of patients with primary nodal DLBCL are classified as clinical stage III-IV $(18,19)$, whereas only $38.3 \%$ of patients in the present study exhibited stage III-IV disease, a difference that may be the consequence of the variation in the definition of primary extra-nodal involvement, or differences in staging criteria. When lymphomas presented at extra-nodal organs with distant lymph node, spleen or thymus involvement, they were categorized as primary nodal NHL, leading to more patients being classified as stage I-II.

For PE-DLBCL patients with localized lesions, neither surgery nor radiotherapy alone is preferred, and the choice of treatment strategies should be adjusted according to the stratification of anatomic location and disease stage. Several studies have demonstrated improved OS in the groups of patients with PGI-DLBCL who underwent surgery combined with $\mathrm{CT}$, particularly in those with early disease stages (20-23). However, certain centers suggest that patients with stage I-II PGFS-DLBCL should be treated with systemic $\mathrm{CT}$ and localized RT or surgery to optimize chances of remission (24-26). In previous studies, mastectomy was reported to be non-beneficial for patients with PB-DLBCL (27-29) or PT-DLBCL (30-32), and the International Extra-Nodal Lymphoma Study Group (IELSG) revealed that radical mastectomy is an adverse factor for cause-specific survival in multivariate analysis (29). In the present study, mastectomy combined with CT was not associated with improved outcomes in patients with primary GI tract, FGS, breast or thyroid involvement. Surgery was performed on 15 patients with PGI-DLBCL who required pathological diagnosis, and 8 who were experiencing bleeding, perforation or other acute complications, delaying the commencement of $\mathrm{CT}$, with a detrimental outcome. Limited by the small number of patients with primary breast, FGS or thyroid involvement, and due to the study's retrospective nature and lack of randomized comparisons, the present study has not reliably assessed the effect of surgery on survival.

HD-MTX is considered to be the most effective agent for treating PCNS-DLBCL (33), and the addition of high-dose cytarabine (HD-Ara-C) has been demonstrated to significantly improve the RR and failure-free survival $(34,35)$. The efficacy of adding of whole brain RT (WBRT) to HD-MTX-based CT as consolidative therapy is debatable. Doses of 30-36 Gy to the whole brain are currently used (36-39), but certain studies do 


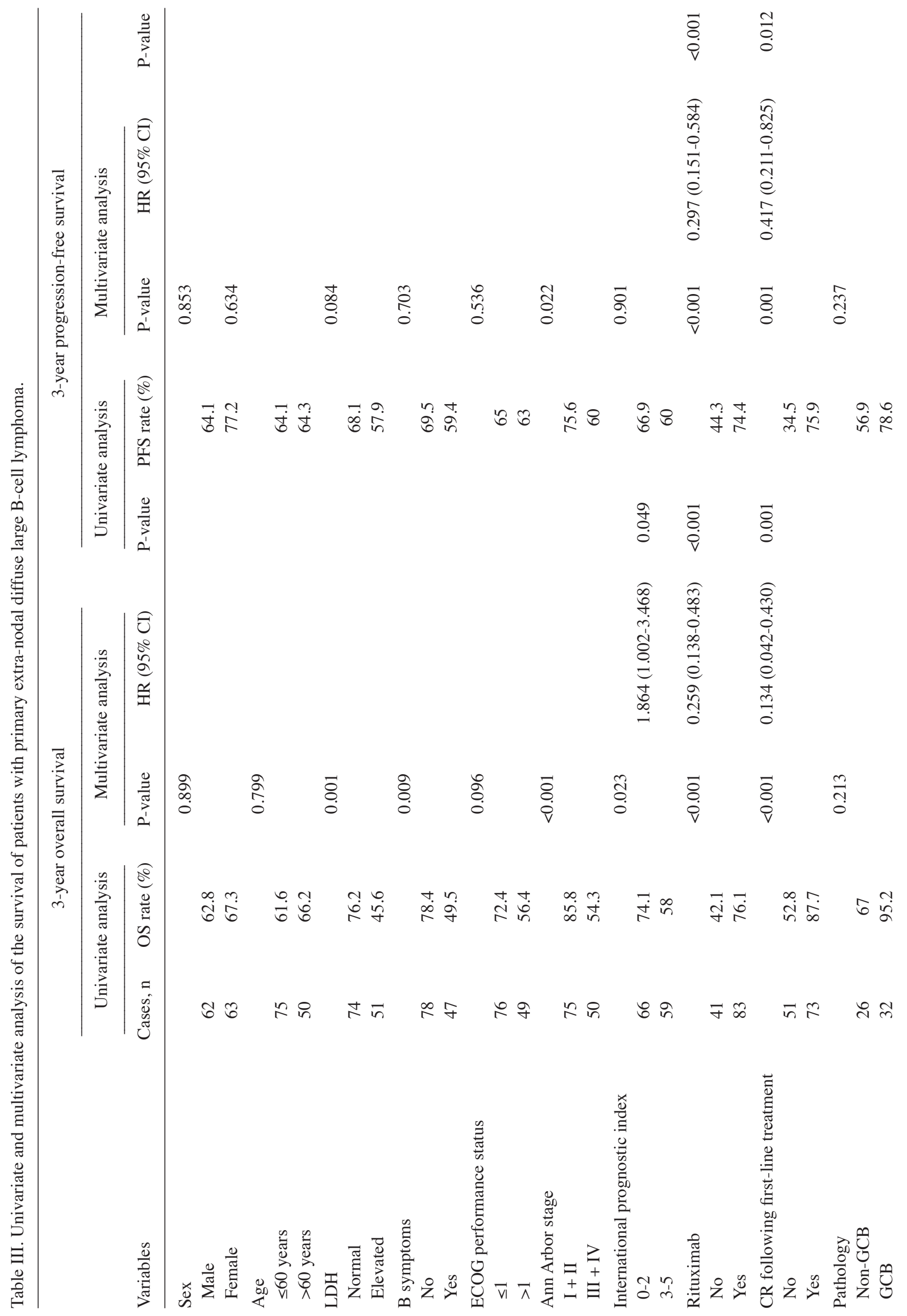




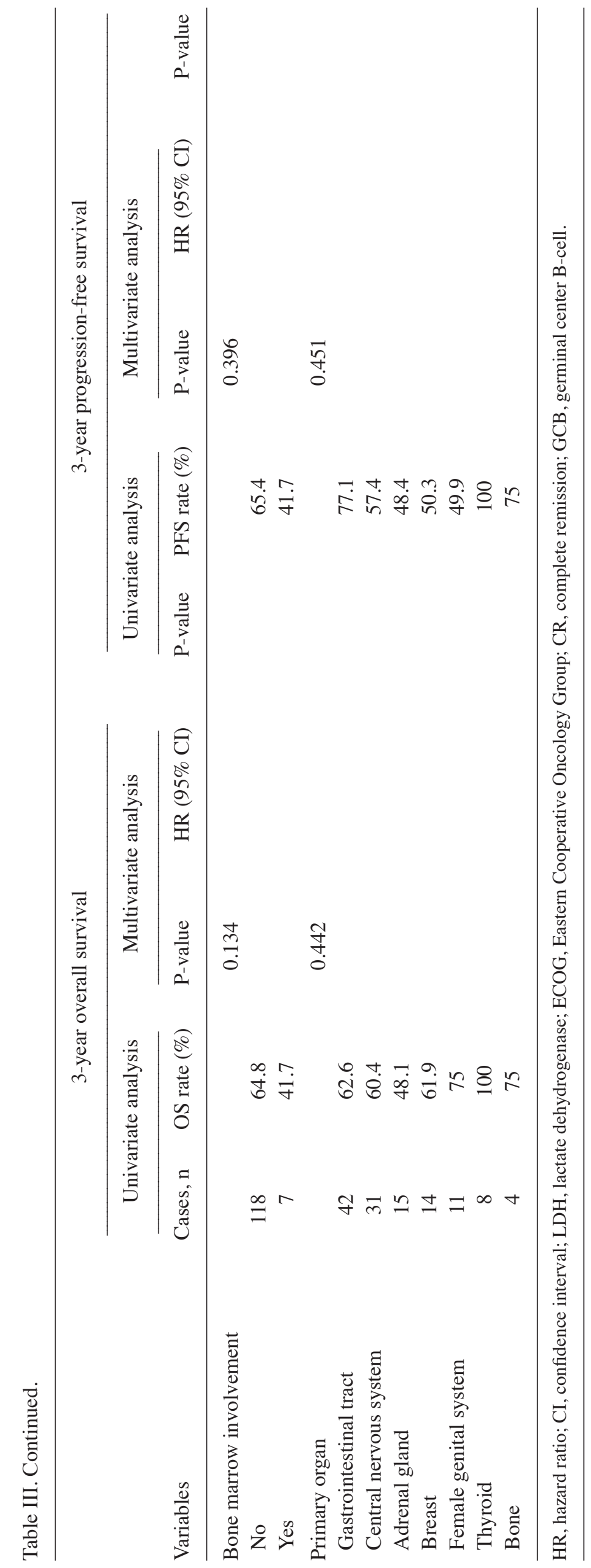


A

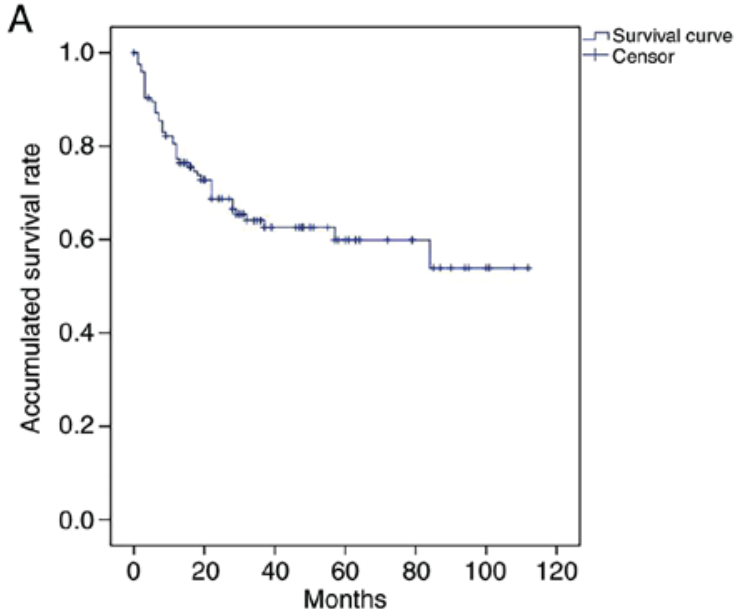

B

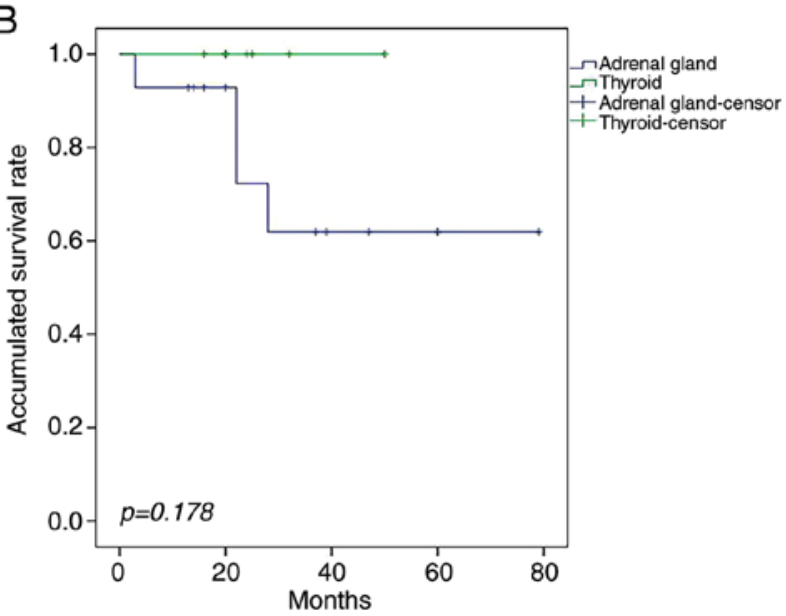

Figure 1. Overall survival for patients with PE-DLBCL or PT-DLBCL. (A) As demonstrated by the Kaplan-Meier curve, the 3-year overall survival rate for patients with PE-DLBCL was $64.1 \%$. (B) Compared with the patients with PA-DLBCL, the patients with PT-DLBCL experienced an improved prognosis. However, this difference was not statistically significant $(\mathrm{P}=0.178)$. PE-DLBCL primary extra-nodal diffuse large B-cell lymphoma, PT-DLBCL primary thyroid diffuse large B cell lymphoma, PA-DLBCL, primary adrenal gland diffuse large B cell lymphoma.

not report a clear benefit of WBRT in prolonging OS (40-42). In the present study, WBRT with CT improved the 3-year OS rate, but the difference was not statistically significant, potentially due to the fact that 5 of the 9 patients who underwent CT combined with WBRT selected RT as salvage therapy, and 3 patients began RT prior to achieving CR. Nonetheless, there is a general agreement that WBRT is associated with delayed treatment-associated neurotoxicity and that it may hinder the benefits of disease control (40-42). Recently, Ibrutinib (43) and Nivolumab (44) were reported to be active in relapsed/refractory PCNS lymphoma, as previous studies have demonstrated that PCNS-DLBCL is characterized by a high expression of myeloid differentiation primary response 88 (MYD88) (45-47), and programmed death (PD)-1/PD-ligand 1 is immunohistochemically and genetically detectable $(48,49)$. These studies outline potential future treatments for PCNS-DLBCL.

In the present study, three main prognostic factors were identified that influenced survival-rituximab, IPI and achieving CR following first-line therapy. The wide application of rituximab, R-CHOP or R-CHOP-like regimens have achieved significant therapeutic effects in DLBCL (50). At present, systemic CT is accepted as the cornerstone of PE-DLBCL treatment, but a general consensus regarding the therapeutic effect of rituximab in PE-DLBCL has not been reached. A single-center study retrospectively analyzed 48 PE-NHL patients and confirmed that combined rituximab therapy did not improve OS $(\mathrm{P}=0.361)$, likely influenced by the selection bias for patients whose primary sites were adrenal, ovarian or pancreatic; other commonly involved organs, including the GI tract, were excluded (7). However, other studies have demonstrated that rituximab may improve the OS and PFS of patients with DLBCL with primary GI tract, adrenal and breast involvement (51-55). The present study demonstrated that the addition of rituximab to CT significantly improved the OS and PFS rates of patients with PE-DLBCL. However, as it was a non-randomized comparison, future prospective studies are required to confirm this observation.

IPI and its variants are the main prognostic tools used in patients with DLBCL and, in the present study, the 3-year
OS rates were $82.1,61.2,50.0$ and $46.1 \%$ for patients in low, low-intermediate, high-intermediate and high-risk groups, respectively. The difference was statistically significant, and the multivariate analysis also indicated that IPI $\geq 2$ was an independent risk factor for PE-DLBCL. Therefore, IPI was also suitable for assessing the prognosis of patients with PE-DLBCL ( $\mathrm{P}=0.017)$.

Recent studies have demonstrated that patients with DLBCL may be divided into two groups of different prognoses using the Hans classification; in addition, the germinal center $\mathrm{B}$-cell (GCB) type is associated with a better prognosis than the non-GCB type $(56,57)$. Furthermore, it has been reported that the majority of patients with primary breast, adrenal and CNS DLBCL are of the non-GCB type (52,58-63). In the present study, a total $44 / 67$ patients were non-GCB type, and primary CNS (14/17) and adrenal gland (5/5) accounted for the majority of these cases. The 3-year OS rate for GCB was not significantly higher than non-GCB, perhaps because the origin of the cells or the genetic causes of PE-DLBCL were different from those of primary intra-nodal DLBCL, as studies have demonstrated that PCNS-DLBCL is primarily non-GCB, but sequencing suggests that the cell source of original nodal non-GCB DLBCL and PCNS-DLBCL are different (64).

There are discrepancies in the prognosis of PE-DLBCL originating from different sites. Primary thyroid lymphoma (PTL) is associated with a relatively favorable prognosis $(32,65,66)$, and in a study considering 108 cases of PTL, there was no mortality in the follow-up period for patients with stage I disease (65). The reason for this may be that $\sim 90 \%$ of these patients were diagnosed at an early stage $(32,65)$. However, the prognosis for PA-DLBCL is relatively poor $(52,67)$, and the event-free survival for elderly patients with PA-DLBCL was only $12-18$ months $(68,69)$. In the present study, the 3-year OS rates for PT-DLBCL and PA-DLBCL were 100 and 48.1\%, respectively. However, since the number of PT-DLBCL cases was small, the difference was not statistically significant.

A number of centers have reported that involvement of the breast, renal, adrenal or female reproductive system is 

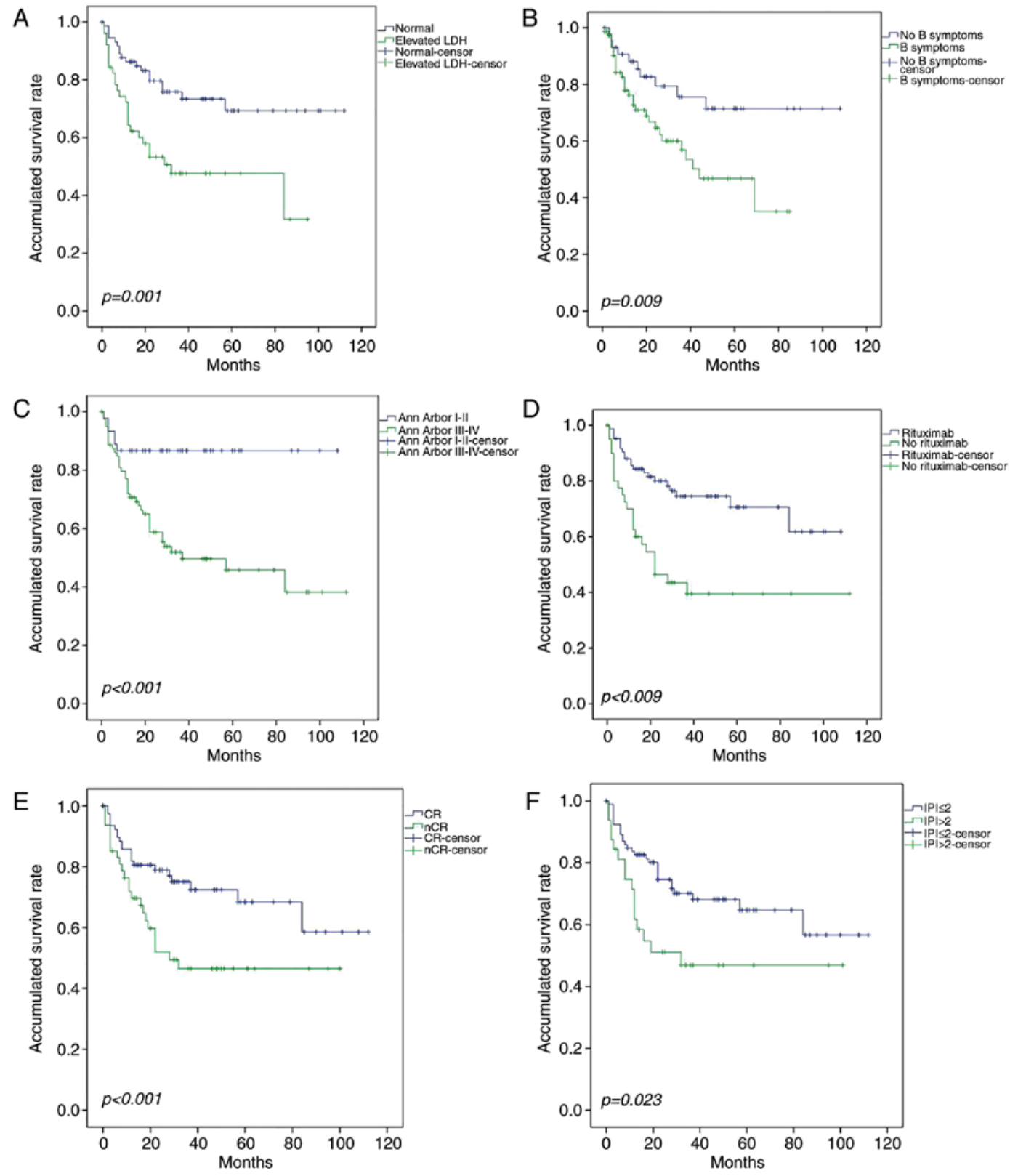

Figure 2. Identification of risk factors in PE-DLBCL. Univariate analysis demonstrated that (A) elevated LDH, (B) B symptoms, (C) Ann Arbor stage III-IV, (D) lack of treatment with rituximab, (E) CR not achieved following first-line treatment and (F) IPI $>2$ were risk factors for PE-DLBCL. PE-DLBCL, primary extra-nodal diffuse large B-cell lymphoma; LDH, lactate dehydrogenase; $\mathrm{CR}$, complete remission; IPI, International prognostic index.

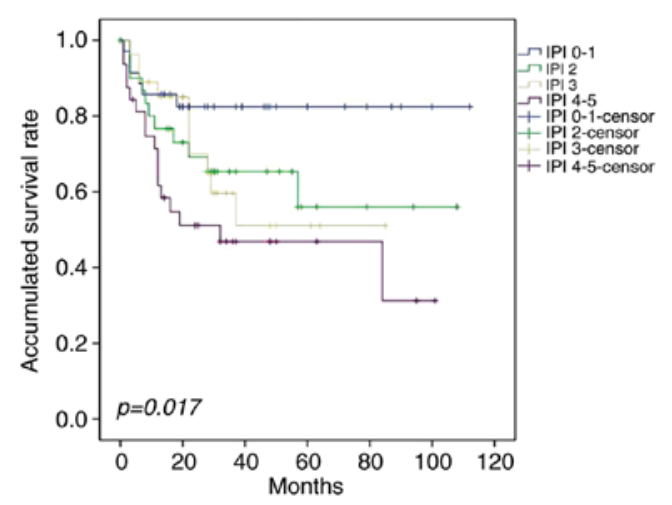

Figure 3. Overall survival for patients stratified by IPI score. The difference in survival rates for patients with IPI low risk, low-intermediate risk, high-intermediate risk and high risk was statistically significant $(\mathrm{P}=0.017)$. IPI, International prognostic index. associated with a high risk of CNS recurrence (7,70-75), but the mechanism of this remains unclear. L265P mutations of MYD88 are common in PCNS-DLBCLs (38-75\%) $(45,76,77)$, and these mutations were predominantly present in primary testicle and breast DLBCLs, whereas the mutation rate in PGI-DLBCL was relatively low $(76,78)$. These observations indicate that the mutation of MYD88 may be associated with the preferential dissemination to CNS. In the present study, PFGS-DLBCL and PA-DLBCL were risk factors, as determined by multivariate analysis; our previous study demonstrated that patients with PFGS-DLBCL have a high frequency of MYD88 mutations (61). However, we have not yet sequenced the specimens from patients with PA-DLBCL, and the reason patients with PA-DLBCLs are more likely to experience CNS relapse remains unclear. It is possible that PE-DLBCL involves organs with preferential dissemination 
Table IV. Survival analysis of patients with primary extra-nodal diffuse large B-cell lymphoma treated with chemotherapy combined with surgery.

\begin{tabular}{|c|c|c|c|c|c|c|}
\hline \multirow[b]{2}{*}{ Primary organ } & \multicolumn{3}{|c|}{ 3-year overall survival rate (\%) } & \multicolumn{3}{|c|}{ 3-year progression free survival rate $(\%)$} \\
\hline & Chemotherapy & $\begin{array}{c}\text { Chemotherapy + } \\
\text { surgery }\end{array}$ & P-value & Chemotherapy & $\begin{array}{c}\text { Chemotherapy + } \\
\text { surgery }\end{array}$ & P-value \\
\hline Gastrointestinal tract & 77.9 & 68.4 & 0.622 & 90 & 100 & 0.254 \\
\hline Female genital system & 66.7 & 87.5 & 0.592 & 66.7 & 50 & 0.955 \\
\hline Breast & 53.3 & 75 & 0.479 & 25 & 75 & 0.257 \\
\hline
\end{tabular}
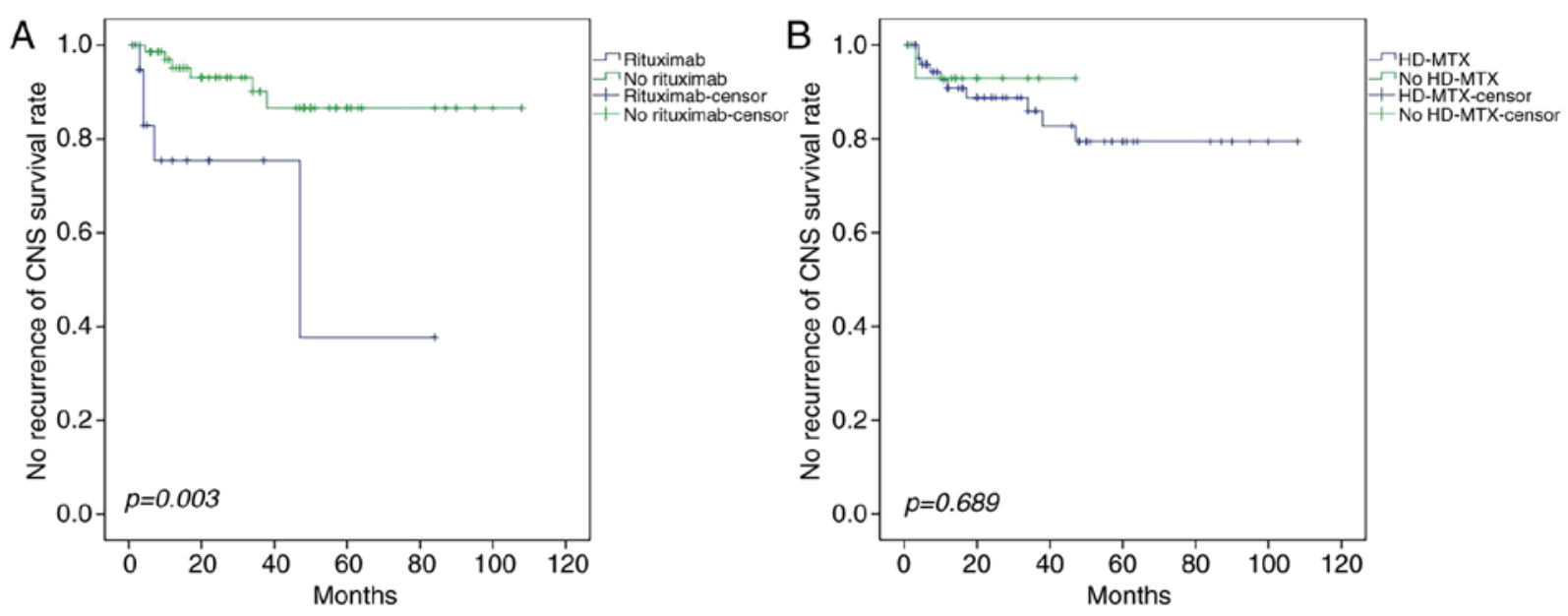

Figure 4. Effect of rituximab and HD-MTX on survival rate. (A) Patients receiving the R-CHOP regimen exhibited a lower incidence of CNS recurrence than those receiving the CHOP regimen. (B) Intravenous infusion of HD-MTX combined with CHOP yielded no significant difference in the CNS recurrence rate compared with those who did not receive HD-MTX. HD-MTX, high-dose methotrexate; R-CHOP, rituximab, cyclophosphamide, doxorubicin, vindesine, and prednisone; CNS, central nervous system; CHOP, cyclophosphamide, doxorubicin, vindesine and prednisone.

to the CNS, representing a distinct cohort of DLBCL driven by equivalent oncogenic mutations. However, a large cohort study is required to confirm this hypothesis, and further molecular analysis may elucidate the specific nature of extra-nodal DLBCLs with preferential dissemination to CNS.

Patients with the recurrence of NHL in the CNS exhibit a poor prognosis, and solving this problem is urgent. Intrathecal MTX is used to prevent CNS relapse, but the present study revealed that it did not provide sufficient prevention $(\mathrm{P}=0.876)$, consistent with previous reports $(66,79)$. The reason for this may be that CNS recurrence is more frequent in the parenchyma than the meninges and thus, the typical intrathecal injection is less effective. A multicenter retrospective analysis revealed that the continuous intravenous infusion of HD-MTX $\left(1-3 \mathrm{~g} / \mathrm{m}^{2}\right)$ over $24 \mathrm{~h}$ may reduce the likelihood of CNS recurrence (80). In the present study, the CNS RFS for patients who received HD-MTX $\left(1 \mathrm{~g} / \mathrm{m}^{2}\right)$ was not significantly higher than that in untreated patients. This may be because there were too few cases for the data to reach significance, or because the concentration of MTX in the cerebrospinal fluid (CSF) may not have reached $0.5 \mathrm{mmol} / 1$, which is the concentration required to kill tumor cells (81). Therefore, the detection of the concentration of MTX in the CSF requires further investigation.
The addition of rituximab has improved the outcomes in DLBCL, but there is no general consensus regarding the impact of rituximab in preventing CNS recurrence. Certain studies have indicated that rituximab may reduce CNS recurrence (82-85), while others have suggested that adding rituximab did not lower the incidence of CNS recurrence $(86,87)$. The present study demonstrated that CT combined with rituximab may effectively prevent CNS recurrence. Considering that only $1 \%$ of the rituximab dose can cross the blood-brain barrier, the present study revealed that it significantly improved the OS and PFS of patients with PE-DLBCL, indicating that rituximab may lower the risk of recurrent CNS by reducing the tumor burden.

In summary, the overall prognosis of patients with PE-DLBCL was analyzed, and it was revealed that CT, whether combined with surgery or RT, did not improve the prognosis of patients. Therefore, it is advisable that surgery is used for diagnosing and treating acute complications. However, the implications of the present study are limited by the number of patients; a study with a larger cohort is required. Preventing CNS relapse is urgent; and patients with primary FGS and adrenal gland involvement were identified as exhibiting an increased risk. Treatment with rituximab was demonstrated to be effective for CNS relapse prevention. Additionally, the intravenous infusion of HD-MTX 
Table V. Univariate and multivariate analysis of risk factors for CNS relapse.

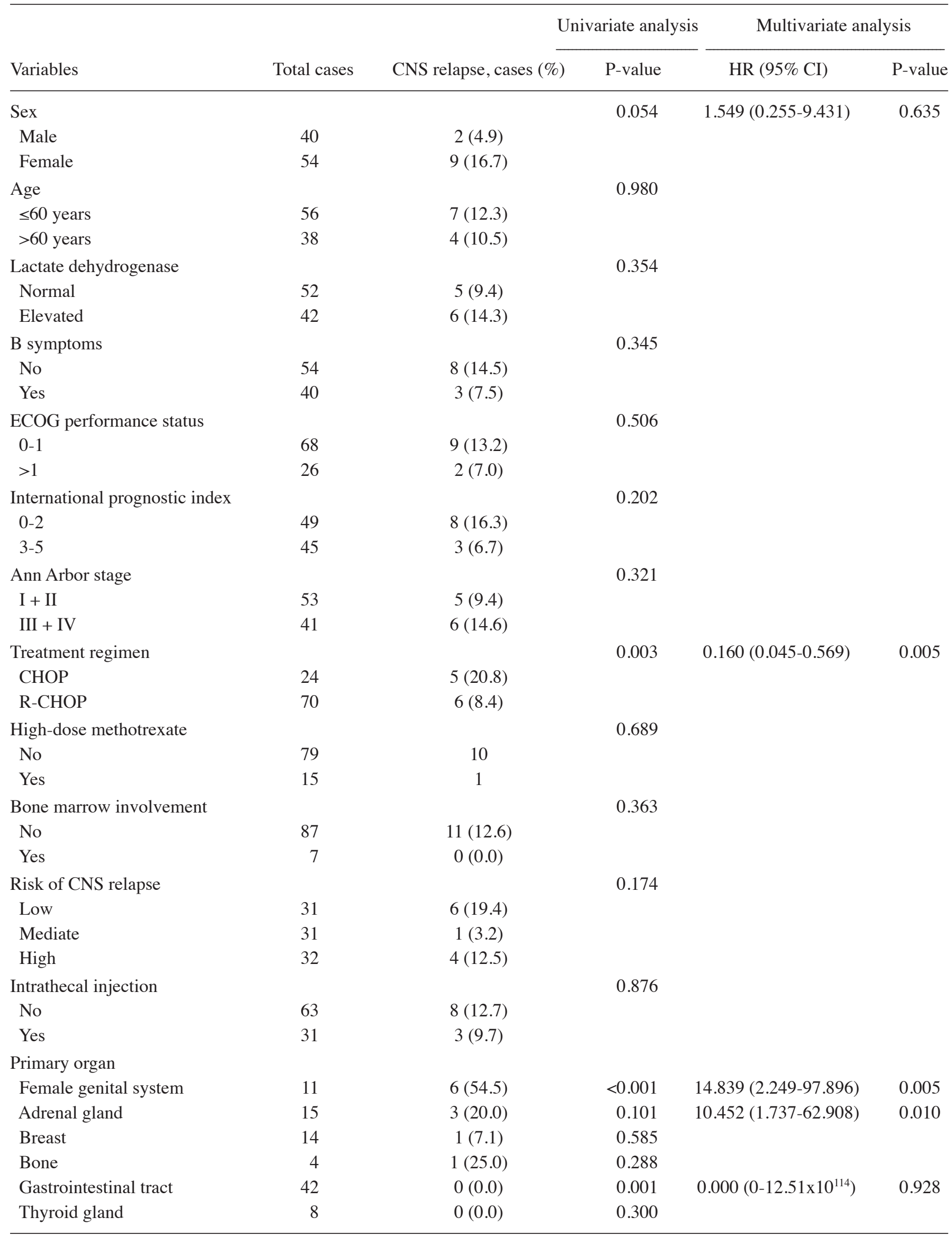

CNS, central nervous system; HR, hazard ratio; CI, confidence interval; ECOG, Eastern Cooperative Oncology Group; CHOP, cyclophosphamide, doxorubicin, vindesine and prednisone; R-CHOP, rituximab, cyclophosphamide, doxorubicin, vindesine, and prednisone. 
lowered the rate of CNS relapse, although the effect was not statistically significant. Therefore, future studies with larger sample sizes are required to fully elucidate the efficacy of rituximab.

\section{Acknowledgements}

Not applicable.

\section{Funding}

CAMS Innovation Fund for Medical Sciences (CIFMS) 2016-12M-1-001 Capital Foundation of Medical Developments (CFMD) 016-2-4016 Pumch Science Fund for Junior Faculty 2016-1.19. This funding provided the help of data analysis.

\section{Availability of data and materials}

All data generated or analyzed during this study are included in this published article.

\section{Author's contributions}

HS analyzed and interpreted the patient data and was a major contributor in writing the manuscript. DZ and ZW conceived and designed the work that led to the submission, acquired data and had an important role in interpreting the results. YZ, $\mathrm{XH}, \mathrm{WW}, \mathrm{LZ}, \mathrm{CY}$ and JF participated in the diagnosis and treatment of patients and provided the clinical data, they also contributed significantly to acquisition and analysis of data, drafting the manuscript and revising it critically. JF gave final approval of the version to be published. All authors read and approved the final manuscript.

\section{Ethics approval and consent to participate}

All procedures followed were in accordance with the ethical standards of the responsible committee on human experimentation (institutional and national) and with the Helsinki Declaration of 1975, as revised in 2000 (5). Informed consent was obtained from all patients for being included in the study.

\section{Consent for publication}

Not applicable.

\section{Competing interests}

The authors declare that they have no competing interests.

\section{References}

1. Economopoulos T, Asprou N, Stathakis N, Papageorgiou E, Dervenoulas J, Xanthaki K and Raptis S: Primary extranodal non-Hodgkin's lymphoma in adults: Clinicopathological and survival characteristics. Leuk Lymphoma 21: 131-136, 1996.

2. Vitolo U, Seymour JF, Martelli M, Illerhaus G, Illidge T, Zucca E, Campo E, Ladetto $\mathrm{M}$ and ESMOGuidelines Committee: Extranodal diffuse large B-cell lymphoma (DLBCL) and primary mediastinal B-cell lymphoma: ESMO clinical practice guidelines for diagnosis, treatment and follow-up. Ann Oncol 27(Suppl 5): v91-v102, 2016.
3. Rudders RA, Ross ME and DeLellis RA: Primary extranodal lymphoma: Response to treatment and factors influencing prognosis. Cancer 42: 406-416, 1978.

4. Paryani S, Hoppe RT, Burke JS, Sneed P, Dawley D, Cox RS, Rosenberg SA and Kaplan HS: Extralymphatic involvement in diffuse non-Hodgkin's lymphoma. J Clin Oncol 1: 682-688, 1983.

5. d'Amore F, Christensen BE, Brincker H, Pedersen NT, Thorling K, Hastrup J, Pedersen M, Jensen MK, Johansen P and Andersen E: Clinicopathological features and prognostic factors in extranodal non-hodgkin lymphomas. Danish LYFO study group. Eur J Cancer 27: 1201-1208, 1991.

6. AlShemmari SH, Ameen RM and Sajnani KP: Extranodal lymphoma: A comparative study. Hematology 13: 163-169, 2008

7. Yun J, Kim SJ, Won JH, Choi CW, Eom HS, Kim JS, Kim MK, Kwak JY, Kim WS and Suh C: Clinical features and prognostic relevance of ovarian involvement in non-Hodgkin's lymphoma: A Consortium for Improving Survival of Lymphoma (CISL) report. Leuk Res 34: 1175-1179, 2010.

8. Freeman C, Berg JW and Cutler SJ: Occurrence and prognosis of extranodal lymphomas. Cancer 29: 252-260, 1972.

9. Reddy S, Pellettiere E, Saxena V and Hendrickson FR: Extranodal non-Hodgkin's lymphoma. Cancer 46: 1925-1931, 1980.

10. Zhang J, Chen $\mathrm{B}$ and $\mathrm{Xu} \mathrm{X}$ : Impact of rituximab on incidence of and risk factors for central nervous system relapse in patients with diffuse large B-cell lymphoma: A systematic review and meta-analysis. Leuk Lymphoma 55: 509-514, 2014.

11. Jaffe ES: The 2008 WHO classification of lymphomas: Implications for clinical practice and translational research. Hematology Am Soc Hematol Educ Program 523-531, 2009.

12. Carbone PP, Kaplan HS, Musshoff K, Smithers DW and Tubiana M: Report of the committee on hodgkin's disease staging classification. Cancer Res. 31: 1860-1861, 1971.

13. International Non-Hodgkin's Lymphoma Prognostic Factors Project: A predictive model for aggressive non-Hodgkin's lymphoma. N Engl J Med 329: 987-994, 1993.

14. Cheson BD, Fisher RI, Barrington SF, Cavalli F, Schwartz LH, Zucca E and Lister TA: Recommendations for initial evaluation, staging, and response assessment of Hodgkin and non-Hodgkin lymphoma: The Lugano classification. J Clin Oncol 32: 3059-3068, 2014.

15. Zelenetz AD, Gordon LI, Wierda WG, Abramson JS, Advani RH, Andreadis CB, Bartlett N, Bellam N, Byrd JC, Czuczman MS, et al: Non-Hodgkin's lymphomas, version 2.2014. J Natl Compr Canc Netw 12: 916-946, 2014.

16. Cheson BD, Pfistner B, Juweid ME, Gascoyne RD, Specht L, Horning SJ, Coiffier B, Fisher RI, Hagenbeek A, Zucca E, et al: Revised response criteria for malignant lymphoma. J Clin Oncol 25: 579-586, 2007.

17. Oken MM, Creech RH, Tormey DC, Horton J, Davis TE, McFadden ET and Carbone PP: Toxicity and response criteria of the eastern cooperative oncology group. Am J Clin Oncol 5: 649-655, 1982.

18. A clinical evaluation of the international lymphoma study group classification of non-hodgkin's lymphoma. The non-hodgkin's lymphoma classification project. Blood 89: 3909-3918, 1997.

19. Armitage JO and Weisenburger DD: New approach to classifying non-Hodgkin's lymphomas: Clinical features of the major histologic subtypes. Non-hodgkin's lymphoma classification project. J Clin Oncol 16: 2780-2795, 1998.

20. Khosla D, Kumar R, Kapoor R, Kumar N, Bera A and Sharma SC: A retrospective analysis of clinicopathological characteristics, treatment, and outcome of 27 patients of primary intestinal lymphomas. J Gastrointest Cancer 44: 417-421, 2013.

21. Gou H, Zang J, Jiang M, Yang Y, Cao D and Chen X: Clinical prognostic analysis of 116 patients with primary intestinal non-hodgkin lymphoma. Med Oncol 29: 227-234, 2012.

22. Kim SJ, Choi CW, Mun Y, Oh SY, Kang HJ, Lee SI, Won JH, Kim MK, Kwon JH, Kim JS, et al: Multicenter retrospective analysis of 581 patients with primary intestinal non-hodgkin lymphoma from the Consortium for Improving Survival of Lymphoma (CISL). BMC Cancer 11: 321, 2011.

23. Kim SJ, Kang HJ, Kim JS, Oh SY, Choi CW, Lee SI, Won JH, Kim MK, Kwon JH, Mun Y, et al: Comparison of treatment strategies for patients with intestinal diffuse large B-cell lymphoma: Surgical resection followed by chemotherapy versus chemotherapy alone. Blood 117: 1958-1965, 2011.

24. Frey NV, Svoboda J, Andreadis C, Tsai DE, Schuster SJ, Elstrom R, Rubin SC and Nasta SD: Primary lymphomas of the cervix and uterus: The University of Pennsylvania's experience and a review of the literature. Leuk Lymphoma 47: 1894-1901, 2006. 
25. Miller TP, Dahlberg S, Cassady JR, Adelstein DJ, Spier CM Grogan TM, LeBlanc M, Carlin S, Chase E and Fisher RI: Chemotherapy alone compared with chemotherapy plus radiotherapy for localized intermediate- and high-grade non-Hodgkin's lymphoma. N Engl J Med 339: 21-26, 1998.

26. Cheng H, Tang X, Cheng J, Zhang B, Zhang YL, Wang WQ and Teng P: Pathologic character and diagnosis of female primary genital system diffuse large B cell lymphoma. Eur Rev Med Pharmacol Sci 21: 1471-1476, 2017.

27. Aviv A, Tadmor T and Polliack A: Primary diffuse large B-cell lymphoma of the breast: Looking at pathogenesis, clinical issues and therapeutic options. Ann Oncol 24: 2236-2244, 2013.

28. Jennings WC, Baker RS, Murray SS, Howard CA, Parker DE, Peabody LF, Vice HM, Sheehan WW and Broughan TA: Primary breast lymphoma: The role of mastectomy and the importance of lymph node status. Ann Surg 245: 784-789, 2007.

29. Ryan G, Martinelli G, Kuper-Hommel M, Tsang R, Pruneri G, Yuen K, Roos D, Lennard A, Devizzi L, Crabb S, et al: Primary diffuse large b-cell lymphoma of the breast: Prognostic factors and outcomes of a study by the international extranodal lymphoma study group. Ann Oncol 19: 233-241, 2008.

30. Ha CS, Shadle KM, Medeiros LJ, Wilder RB, Hess MA, Cabanillas F and Cox JD: Localized non-Hodgkin lymphoma involving the thyroid gland. Cancer 91: 629-635, 2001.

31. Pyke CM, Grant CS, Habermann TM, Kurtin PJ, van Heerden JA, Bergstralh EJ, Kunselman A and Hay ID: Non-Hodgkin's lymphoma of the thyroid: Is more than biopsy necessary? World J Surg 16: 604-609 discussion 609-10, 1992.

32. Meyer-Rochow GY, Sywak MS, Reeve TS, Delbridge LW and Sidhu SB: Surgical trends in the management of thyroid lymphoma. Eur J Surg Oncol 34: 576-580, 2008.

33. Abrey LE, Ben-Porat L, Panageas KS, Yahalom J, Berkey B Curran W, Schultz C, Leibel S, Nelson D, Mehta M and DeAngelis LM: Primary central nervous system lymphoma: The memorial sloan-kettering cancer center prognostic model. J Clin Oncol 24: 5711-5715, 2006.

34. Ferreri AJ, Reni M, Foppoli M, Martelli M, Pangalis GA, Frezzato M, Cabras MG, Fabbri A, Corazzelli G, Ilariucci F, et al: High-dose cytarabine plus high-dose methotrexate versus high-dose methotrexate alone in patients with primary CNS lymphoma: A randomised phase 2 trial. Lancet 374: 1512-1520, 2009.

35. Ferreri AJ, Cwynarski K, Pulczynski E, Ponzoni M, Deckert M, Politi LS, Torri V, Fox CP, Rosee PL, Schorb E, et al: Chemoimmunotherapy with methotrexate, cytarabine, thiotepa, and rituximab (matrix regimen) in patients with primary cns lymphoma: Results of the first randomisation of the international extranodal lymphoma study group-32 (ielsg32) phase 2 trial. Lancet Haematol 3: e217-e227, 2016.

36. Hoang-Xuan K, Bessell E, Bromberg J, Hottinger AF, Preusser M, Ruda R, Schlegel U, Siegal T, Soussain C, Abacioglu U, et al: Diagnosis and treatment of primary CNS lymphoma in immunocompetent patients: Guidelines from the european association for neuro-oncology. Lancet Oncol 16: e322-e332, 2015.

37. Morris PG, Correa DD, Yahalom J, Raizer JJ, Schiff D, Grant B Grimm S, Lai RK, Reiner AS, Panageas K, et al: Rituximab, methotrexate, procarbazine, and vincristine followed by consolidation reduced-dose whole-brain radiotherapy and cytarabine in newly diagnosed primary CNS lymphoma: Final results and long-term outcome. J Clin Oncol 31: 3971-3979, 2013.

38. Pels $\mathrm{H}$ and Schlegel U: Primary central nervous system lymphoma. Curr Treat Options Neurol 8: 346-357, 2006.

39. Shah GD, Yahalom J, Correa DD, Lai RK, Raizer JJ, Schiff D, LaRocca R, Grant B, DeAngelis LM and Abrey LE: Combined immunochemotherapy with reduced whole-brain radiotherapy for newly diagnosed primary CNS lymphoma. J Clin Oncol 25: 4730-4735, 2007.

40. Thiel E, Korfel A, Martus P, Kanz L, Griesinger F, Rauch M, Roth A, Hertenstein B, von Toll T, Hundsberger T, et al: High-dose methotrexate with or without whole brain radiotherapy for primary CNS lymphoma (G-PCNSL-SG-1): A phase 3, randomised, non-inferiority trial. Lancet Oncol 11: 1036-1047, 2010.

41. Herrlinger U, Schafer N, Fimmers R, Griesinger F, Rauch M, Kirchen H, Roth P, Glas M, Bamberg M, Martus P, et al: Early whole brain radiotherapy in primary CNS lymphoma: Negative impact on quality of life in the randomized G-PCNSL-SG1 trial. J Cancer Res Clin Oncol 143: 1815-1821, 2017.

42. DeAngelis LM, Seiferheld W, Schold SC, Fisher B, Schultz CJ and Radiation Therapy Oncology Group Study 93-10: Combination chemotherapy and radiotherapy for primary central nervous system lymphoma: Radiation therapy oncology group study 93-10. J Clin Oncol 20: 4643-4648, 2002
43. Grommes C, Pastore A, Palaskas N, Tang SS, Campos C, Schartz D, Codega P, Nichol D, Clark O, Hsieh W, et al: Ibrutinib unmasks critical role of bruton tyrosine kinase in primary cns lymphoma. Cancer Discov 7: 1018-1029, 2017.

44. Nayak L, Iwamoto FM, LaCasce A, Mukundan S, Roemer MGM, Chapuy B, Armand P, Rodig SJ and Shipp MA: PD-1 blockade with nivolumab in relapsed/refractory primary central nervous system and testicular lymphoma. Blood 129: 3071-3073, 2017.

45. Montesinos-Rongen M, Godlewska E, Brunn A, Wiestler OD, Siebert R and Deckert M: Activating L265P mutations of the MYD88 gene are common in primary central nervous system lymphoma. Acta Neuropathol 122:791-792, 2011.

46. Kim Y, Ju H, Kim DH, Yoo HY, Kim SJ, Kim WS and Ko YH: CD79B and MYD88 mutations in diffuse large B-cell lymphoma. Hum Pathol 45: 556-564, 2014.

47. Zheng M, Perry AM, Bierman P, Loberiza F Jr, Nasr MR, Szwajcer D, Del Bigio MR, Smith LM, Zhang W and Greiner TC: Frequency of MYD88 and CD79B mutations, and MGMT methylation in primary central nervous system diffuse large B-cell lymphoma. Neuropathology 37: 509-516, 2017.

48. Berghoff AS, Ricken G, Widhalm G, Rajky O, Hainfellner JA, Birner P, Raderer M and Preusser M: PD1 (CD279) and PD-L1 (CD274, B7H1) expression in primary central nervous system lymphomas (PCNSL). Clin Neuropathol 33: 42-49, 2014.

49. Chapuy B, Roemer MG, Stewart C, Tan Y, Abo RP, Zhang L, Dunford AJ, Meredith DM, Thorner AR, Jordanova ES, et al: Targetable genetic features of primary testicular and primary central nervous system lymphomas. Blood 127: 869-881, 2016.

50. Pfreundschuh M, Kuhnt E, Trumper L, Osterborg A, Trneny M, Shepherd L, Gill DS, Walewski J, Pettengell R, Jaeger U, et al: CHOP-like chemotherapy with or without rituximab in young patients with good-prognosis diffuse large-B-cell lymphoma: 6-year results of an open-label randomised study of the mabthera international trial (MInT) group. Lancet Oncol 12: 1013-1022, 2011.

51. Li X, Shen W, Cao J, Wang J, Chen F, Wang C, Zou S, Shen B, Zhao R, Li J and Shen Z: Treatment of gastrointestinal diffuse large B cell lymphoma in China: A 10-year retrospective study of 114 cases. Ann Hematol 91: 1721-1729, 2012.

52. Kim YR, Kim JS, Min YH, Hyunyoon D, Shin HJ, Mun YC, Park Y, Do YR, Jeong SH, Park JS, et al: Prognostic factors in primary diffuse large B-cell lymphoma of adrenal gland treated with rituximab-CHOP chemotherapy from the consortium for improving survival of lymphoma (CISL). J Hematol Oncol 5: 49, 2012.

53. Aviles A, Neri N and Nambo MJ: The role of genotype in 104 cases of diffuse large B-cell lymphoma primary of breast. Am J Clin Oncol 35: 126-129, 2012

54. Hu S, Song Y, Li Y, Sun X, Su L, Zhang W, Jia J, Bai O, Liang R, Li X, et al: Primary breast diffuse large B cell lymphoma in the rituximab era: Outcomes of a multicenter retrospective study by the lymphoma and leukemia committee of chinese geriatric oncology society(LLC-CGOS). Blood 128: 4228, 2016.

55. Sun Y, Joks M, Xu LM, Chen XL, Qian D, You JQ and Yuan ZY: Diffuse large B-cell lymphoma of the breast: Prognostic factors and treatment outcomes. Onco Ther 9: 2069-2080, 2016

56. Nyman H, Adde M, Karjalainen-Lindsberg ML, Taskinen M, Berglund M, Amini RM, Blomqvist C, Enblad G and Leppa S: Prognostic impact of immunohistochemically defined germinal center phenotype in diffuse large B-cell lymphoma patients treated with immunochemotherapy. Blood 109: 4930-4935, 2007.

57. Choi WW, Weisenburger DD, Greiner TC, Piris MA, Banham AH, Delabie J, Braziel RM, Geng H, Iqbal J, Lenz G, et al: A new immunostain algorithm classifies diffuse large B-cell lymphoma into molecular subtypes with high accuracy. Clin Cancer Res 15: 5494-5502, 2009

58. Horiguchi K, Hashimoto K, Hashizume M, Masuo T, Suto M, Okajo J, Handa H, Kaneko Y, Yokoo H, Sasaki A, et al: Primary bilateral adrenal diffuse large B-cell lymphoma demonstrating adrenal failure. Intern Med 49: 2241-2246, 2010

59. Hosein PJ, Maragulia JC, Salzberg MP, Press OW, Habermann TM, Vose JM, Bast M, Advani RH, Tibshirani R, Evens AM, et al: A multicentre study of primary breast diffuse large B-cell lymphoma in the rituximab era. Br J Haematol 165: 358-363, 2014.

60. Taniguchi K, Takata K, Chuang SS, Miyata-Takata T, Sato Y, Satou A, Hashimoto Y, Tamura M, Nagakita K, Ohnishi N, et al: Frequent MYD88 L265P and CD79B mutations in primary breast diffuse large B-cell lymphoma. Am J Surg Pathol 40: 324-334, 2016 
61. Cao XX, Li J, Cai H, Zhang W, Duan MH and Zhou DB: Patients with primary breast and primary female genital tract diffuse large B cell lymphoma have a high frequency of MYD88 and CD79B mutations. Ann Hematol 96: 1867-1871, 2017.

62. Lin CH, Kuo KT, Chuang SS, Kuo SH, Chang JH, Chang KC, Hsu HC, Tien HF and Cheng AL: Comparison of the expression and prognostic significance of differentiation markers between diffuse large B-cell lymphoma of central nervous system origin and peripheral nodal origin. Clin Cancer Res 12: 1152-1156, 2006.

63. Braaten KM, Betensky RA, de Leval L, Okada Y, Hochberg FH, Louis DN, Harris NL and Batchelor TT: BCL-6 expression predicts improved survival in patients with primary central nervous system lymphoma. Clin Cancer Res 9: 1063-1069, 2003.

64. Fukumura K, Kawazu M, Kojima S, Ueno T, Sai E, Soda M, Ueda H, Yasuda T, Yamaguchi H, Lee J, et al: Genomic characterization of primary central nervous system lymphoma. Acta Neuropathol 131: 865-875, 2016.

65. Derringer GA, Thompson LD, Frommelt RA, Bijwaard KE, Heffess CS and Abbondanzo SL: Malignant lymphoma of the thyroid gland: A clinicopathologic study of 108 cases. Am J Surg Pathol 24: 623-639, 2000

66. Shimazu Y, Notohara K and Ueda Y: Diffuse large B-cell lymphoma with central nervous system relapse: Prognosis and risk factors according to retrospective analysis from a single-center experience. Int J Hematol 89: 577-583, 2009.

67. Yamamoto E, Ozaki N, Nakagawa M and Kimoto M: Primary bilateral adrenal lymphoma associated with idiopathic thrombocytopenic purpura. Leuk Lymphoma 35: 403-408, 1999.

68. Sonneveld P, de Ridder M, van der Lelie H, Nieuwenhuis K, Schouten H, Mulder A, van Reijswoud I, Hop W and Lowenberg B: Comparison of doxorubicin and mitoxantrone in the treatment of elderly patients with advanced diffuse non-Hodgkin's lymphoma using CHOP versus CNOP chemotherapy. J Clin Oncol 13: 2530-2539, 1995.

69. Bastion Y, Blay JY, Divine M, Brice P, Bordessoule D, Sebban C, Blanc M, Tilly H, Lederlin P, Deconinck E, et al: Elderly patients with aggressive non-Hodgkin's lymphoma: Disease presentation, response to treatment, and survival-a Groupe d'Etude des Lymphomes de l'Adulte study on 453 patients older than 69 years. J Clin Oncol 15: 2945-2953, 1997.

70. Hayase E, Kurosawa M, Yonezumi M and Suzuki S: Early relapse in the central nervous system-after achieving complete response in primary vaginal lymphoma. Rinsho Ketsueki 53: 229-234, 2012 (In Japanese).

71. Yildirim Y: Primary ovarian large B-cell lymphoma in patient with juvenile rheumatoid arthritis treated with low dose Methotrexate. Gynecol Oncol 97: 249-252, 2005.

72. Cohn DE, Resnick KE, Eaton LA, deHart J and Zanagnolo V: Non-Hodgkin's lymphoma mimicking gynecological malignancies of the vagina and cervix: A report of four cases. Int $J$ Gynecol Cancer 17: 274-279, 2007.

73. Hollender A, Kvaloy S, Nome O, Skovlund E, Lote K and Holte H: Central nervous system involvement following diagnosis of non-Hodgkin's lymphoma: A risk model. Ann Oncol 13: 1099-1107, 2002

74. El-Galaly TC, Cheah CY,Hutchings M, Mikhaeel NG, Savage KJ, Sehn LH, Barrington S, Hansen JW, Poulsen MØ, Smith D, et al: Uterine, but not ovarian, female reproductive organ involvement at presentation by diffuse large B-cell lymphoma is associated with poor outcomes and a high frequency of secondary CNS involvement. Br J Haematol 175: 876-883, 2016.

75. Primary adrenal lymphoma with secondary central nervous system involvement: A case report and review of the literature. Turk J Haematol 30: 405-408, 2013.

76. Kraan W, Horlings HM, van Keimpema M, Schilder-Tol EJ, Oud ME, Scheepstra C, Kluin PM, Kersten MJ, Spaargaren M and Pals ST: High prevalence of oncogenic MYD88 and CD79B mutations in diffuse large B-cell lymphomas presenting at immune-privileged sites. Blood Cancer J 3: e139, 2013.
77. Gonzalez-Aguilar A, Idbaih A, Boisselier B, Habbita N, Rossetto M, Laurenge A, Bruno A, Jouvet A, Polivka M, Adam C, et al: Recurrent mutations of MYD88 and TBL1XR1 in primary central nervous system lymphomas. Clin Cancer Res 18: 5203-5211, 2012.

78. Nagakita K, Takata K, Taniguchi K, Miyata-Takata $T$, Sato Y, Tari A, Ohnishi N, Noujima-Harada M, Omote S, Nakamura N, et al: Clinicopathological features of 49 primary gastrointestinal diffuse large B-cell lymphoma cases; comparison with location, cell-of-origin, and frequency of MYD88 L265P. Pathol Int 66: 444-452, 2016.

79. Chua SL, Seymour JF, Streater J, Wolf MM, Januszewicz EH and Prince HM: Intrathecal chemotherapy alone is inadequate central nervous system prophylaxis in patients with intermediate-grade non-Hodgkin's lymphoma. Leuk Lymphoma 43: 1783-1788, 2002.

80. Cheah CY, Herbert KE, O'Rourke K, Kennedy GA, George A, Fedele PL, Gilbertson M, Tan SY, Ritchie DS, Opat SS, et al: A multicentre retrospective comparison of central nervous system prophylaxis strategies among patients with high-risk diffuse large B-cell lymphoma. Br J Cancer 111: 1072-1079, 2014.

81. Vassal G, Valteau D, Bonnay M, Patte C, Aubier F and Lemerle J: Cerebrospinal fluid and plasma methotrexate levels following high-dose regimen given as a 3-hour intravenous infusion in children with nonHodgkin's lymphoma. Pediatr Hemat Oncol 7: 71-77, 1990.

82. Arkenau HT, Chong G, Cunningham D, Watkins D, Agarwal R, Sirohi B, Trumper M, Norman A, Wotherspoon A and Horwich A: The role of intrathecal chemotherapy prophylaxis in patients with diffuse large B-cell lymphoma. Ann Oncol 18: $541-545,2007$.

83. Boehme V, Schmitz N, Zeynalova S, Loeffler $M$ and Pfreundschuh M: CNS events in elderly patients with aggressive lymphoma treated with modern chemotherapy (CHOP-14) with or without rituximab: An analysis of patients treated in the RICOVER-60 trial of the German High-Grade Non-Hodgkin Lymphoma Study Group (DSHNHL). Blood 113: 3896-38902, 2009.

84. Cai QQ, Hu LY, Geng QR, Chen J, Lu ZH, Rao HL, Liu Q, Jiang WQ, Huang HQ, Lin TY and Xia ZJ: New risk factors and new tendency for central nervous system relapse in patients with diffuse large B-cell lymphoma: A retrospective study. Chin J Cancer 35: 87, 2016.

85. Ichikawa S, Fukuhara N, Inoue A, Katsushima H, Ohba R, Katsuoka Y, Onishi Y, Yamamoto J, Sasaki O, Nomura J, et al: Clinicopathological analysis of primary adrenal diffuse large B-cell lymphoma: Effectiveness of rituximab-containing chemotherapy including central nervous system prophylaxis. Exp Hematol Oncol 2: 19, 2013.

86. Kridel R, Telio D, Villa D, Sehn LH, Gerrie AS, Shenkier T, Klasa R, Slack GW, Tan K, Gascoyne RD, et al: Diffuse large $\mathrm{B}$-cell lymphoma with testicular involvement: Outcome and risk of CNS relapse in the rituximab era. Br J Haematol 176: 210-221, 2017.

87. Feugier P, Virion JM, Tilly H, Haioun C, Marit G, Macro M, Bordessoule D, Recher C, Blanc M, Molina T, et al: Incidence and risk factors for central nervous system occurrence in elderly patients with diffuse large-B-cell lymphoma: Influence of rituximab. Ann Oncol 15: 129-133, 2004.

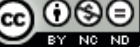

This work is licensed under a Creative Commons Attribution-NonCommercial-NoDerivatives 4.0 International (CC BY-NC-ND 4.0) License. 